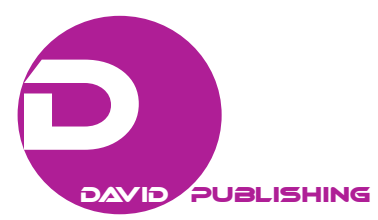

\title{
Determinants of Wages and Labour Supply in the UK*
}

\author{
Keshab Bhattarai \\ University of Hull, Hull, UK
}

\begin{abstract}
We explore characteristics of the UK labour market with special emphasis on explanation of the existing wage inequalities, determinants of participation, and variation in the magnitude of hours of labour supplied among individuals. We explain up to 92 percent of variance in the wage rates from the supply side. Accuracy of the model is accounted by a variety of factors relevant to the labour market such as gender gaps, marital status, on and off the job training, fluency in English, and regional characteristics. The study is quite distinct, since it not only incorporates variables pertinent from the economic point of view, but also some quantified qualitative regressors relating to individuals' opinions and political preferences. Interestingly, we find that the psychological profile of an individual has a very big influence over his decision on whether to participate, but once he joined the labour force his personal beliefs and opinions have no further impact on the probability of finding a job. The chance of being employed once participating depends mainly on the local labour market conditions. We also report unbiased and reliable estimate of labour supply elasticity based on British Household Panel Survey (BHPS) sample.
\end{abstract}

Keywords: labour supply, determinants of wage, participation, self-selection, probabilistic models

\section{Introduction}

The issue of wage and earnings inequality in the British labour market has been a subject of great controversy. Over the last decades a substantial increase in the cross section variance has been observed and documented (Gosling, Machin, \& Meghir, 1996; Dickens, 2000). There is a common consensus among labour economists that schooling, age, gender, job market experience, professional, and vocational background are meaningful factors that can explain part of the existing wage differentials across individuals. However, there is much disagreement on the relative importance of each of these variables for earnings (Rosen, 1972; Mincer, 1974; Spence \& Stiglitz, 1975; Heckman \& Sedlacek, 1985; Shultz, 1998). In this article, we supplement the aggregate evidence with cross-sectional estimates of an earnings function that fits the UK data well. Moreover, we attempt to provide a full description of workers' response to wage changes and model their labour supply decisions in general. In this respect our study makes a major step forward, as it not only demonstrates the impact of economic factors on participation, but also shows how personal beliefs and political alliance are related to willingness to work. The individual's decision-making process is not based solely on a set of economic information, but also on their personal perception of the world and the local environment. For this reason, the psychological profile of an individual can be considered as an extremely relevant factor influencing the decision on whether

* This paper builds on Bhattarai and Wisnieski (2000) Hull Economics working paper; Bhattarai thanks Wisnieski for assisting in this research while he was a final year students in the BSc (Econ) degree.

Keshab Bhattarai, Ph.D., senior lecturer in Economics, Business School, University of Hull, Hull, UK.

Correspondence concerning this article should be addressed to Keshab Bhattarai, Faculty of Business, Law and Politics, Business School, University of Hull, Cottingham Road, Hull, HU6 7RX, UK. 
to enter or remain outside the labour force. Our findings seem to confirm this common sense logic.

Furthermore, we estimate the unbiased elasticity of labour supply with respect to the wages that has meaningful microeconomic and macroeconomic underpinnings. An elastic labour supply curve is a core element of a business cycle (Christiano \& Eichenbaum, 1992), and thus the value of considered elasticity is of major significance for devising policy rules aiming to maximise welfare and to stabilise the economy. Numerous studies of the UK labour market vary tremendously in estimated labour supply elasticities (for literature reviews see Elliot, 1990; Killingsworth, 1983). The most of these studies focus on the supply side of the labour market. Full analysis of the labour market requires a general equilibrium approach (Bhattarai \& Whalley, 1999; Elsby, Shin, \& Solon, 2016).

Big gender differences exist. Unlike the female population, men's behaviour is consistent with being on the downward sloping part of the backward-bending labour supply curve. Despite that, so far there has been no agreement on the sign of the aggregate labour supply elasticity for men and women. Consequently, we reject the group-estimation approach, so frequently seen in the literature. This allows us to focus clearly on the aggregates.

A number of studies exist already to analyse theoretical issues related to wage determination and labour supply (Mroz, 1987; Kennan, 1989; Angrist, 1991; Heckman, 1979; Dougherty \& Jimnenz, 1991). The literature looking upon empirical aspects is also relatively extensive (for the UK Blundell, Duncan, \& Meghir, 1992; Miles, 1997; Dex, Clark, \& Taylor, 1995; and for the U.S. Kimmel \& Kniesner, 1998; Nakamura \& Nakamura, 1981). Our main contribution to the debate is to provide bias-free estimates with a sample big enough to produce reliable results. Moreover, we incorporate a unique set of regressor not present in other studies, but relevant from the statistical point of view. The primary purpose of this article was to introduce a richer structural model that will improve previous cross-sectional studies. We use Wave 8 of the British Household Panel Survey (over 10 thousand individuals) in order to estimate the wages, participation behaviour, and labour supply elasticities. SPSS and Limdep packages are applied for computational purposes.

First, we present the theoretical model of wage determination, methods of resolving self-selection and specification biases, and probabilistic models of participation and employment. In section 3 we proceed onto description of the data set used for this study. Empirical findings on the determinants of wages, participation and labour supply are presented and briefly interpreted in the next section. The study is completed by the conclusions derived from the research in section 5.

\section{Methodology}

\section{The Wage Equation}

We model logarithmic hourly earnings as determined by both the economic and non-economic individual characteristics. Although various functional specifications of the dependent variable have been tried in the literature, the logarithmic form proved to be the most successful one, both in terms of satisfying the assumption of heteroscedasticity assumption and maximising the explanatory power of the regression (Dougherty \& Jimenz, 1991). Due to the fact that the wage level is unobserved for individuals whose market pay is lower than their reservation wage (i.e., for individuals supplying zero hours of labour), the regression is based primarily on a censored sample. We will assume that variations in the individual's offered logarithmic wages are explained by the following equation:

$$
\log \left(\mathrm{w}_{\mathrm{i}}\right)=\beta_{0}+\beta_{1} \mathrm{~S}_{\mathrm{i}}+\beta_{2} \mathrm{Age}_{\mathrm{i}}+\beta_{3} \mathrm{Age}_{\mathrm{i}}^{2}+\beta_{4} \mathrm{VC}_{\mathrm{i}}+\beta_{5} \mathrm{Sex}_{\mathrm{i}}+\beta_{6} \mathrm{E} 2 \mathrm{~L}_{\mathrm{i}}
$$




$$
+\beta_{7} \text { RGSC }_{\mathrm{i}}+\beta_{7} \text { Region }_{\mathrm{i}}+\varepsilon_{\mathrm{i}}^{\mathrm{w}}=\mathrm{X}_{\mathrm{i}}^{\mathrm{w}} \beta+\varepsilon_{\mathrm{i}}^{\mathrm{w}}
$$

where $\mathrm{S}_{\mathrm{i}}$ denotes years of schooling, Age proxies labour market experience, $\mathrm{VC}_{\mathrm{i}}$ is a dichotomous variable taking positive value if considered individual experienced vocational training, $S \mathrm{x}_{\mathrm{i}}$ is a gender dummy ( 1 for Male), E2 $\mathrm{L}_{\mathrm{i}}$ takes a value of 1 if respondent's first language is not English, 0 otherwise, $\mathrm{RGSC}_{\mathrm{i}}$ is a vector of 7 dummies representing RG social class on the most recent job, Region ${ }_{\mathrm{i}}$ is a vector of 19 regional dichotomous variables, and $\varepsilon_{\mathrm{i}}^{\mathrm{W}}$ denotes the disturbance term.

\section{Controlling for Self-selection}

Self-selection bias persists due to the fact that the actual (ex-post) wages for non-workers are unobserved, thus equal to zero (Hausman, 1978; Heckman, 1978; Heckman \& Sadlacek, 1985; Lee, 1982). Nonetheless, had a non-worker been employed, he would have got some pay. In other words, the observed distribution of wage offers is truncated by reservation (shadow) wages. For this reason, any analysis of participation determinants requires a prediction of ex-ante pay for individuals remaining outside paid employment. In order to do so, we utilise a computationally unsophisticated technique (Heckman, 1979) that enables the Probit regression estimates to remain free of sample selection bias.

We assumed above that the observed wages are determined in the following way:

$$
\log \left(\mathrm{w}_{\mathrm{i}}\right)=\mathrm{X}_{\mathrm{i}}^{\mathrm{w}} \beta+\varepsilon_{\mathrm{i}}^{\mathrm{w}}
$$

where $X_{i}{ }^{\mathrm{W}}$ refers to characteristic relevant to the labour market and $\beta$ is a column vector of coefficients. Suppose that one wants to estimate a probabilistic model of participation but data on $\log (\mathrm{w})$ is missing for certain observations. Furthermore, suppose that one can define an indicator $\mathrm{I}_{\mathrm{i}}^{\mathrm{empl}}$, where $\mathrm{I}_{\mathrm{i}}^{\mathrm{empl}}>0$ when the individual $i$ is in paid employment and $\mathrm{I}_{\mathrm{i}}^{\text {empl }}<0$ otherwise (Note, that $\mathrm{I}_{\mathrm{i}}^{\text {empl }}=\mathrm{X}_{\mathrm{i}}^{\text {empl }} \alpha+\varepsilon_{\mathrm{i}}{ }^{\text {empl }}$ and $\mathrm{X}_{\mathrm{i}}^{\text {empl }}$ includes $\mathrm{X}_{\mathrm{i}}^{\mathrm{w}}$ and some other relevant variables). Since the wages are observed only when $\mathrm{I}_{\mathrm{i}}^{\mathrm{empl}}>0$, the wage equation will be of general form:

$$
\mathrm{E}\left(\ln \left(\mathrm{w}_{\mathrm{i}}\right) \mid \mathrm{X}_{\mathrm{i}}^{\mathrm{w}}, \mathrm{I}_{\mathrm{i}}^{\mathrm{empl}}>0\right)=\mathrm{X}_{\mathrm{i}}^{\mathrm{w}} \beta+\mathrm{E}\left(\varepsilon_{\mathrm{i}}^{\mathrm{w}} \mid \mathrm{X}_{\mathrm{i}}^{\mathrm{w}}, \mathrm{I}_{\mathrm{i}}^{\mathrm{empl}}>0\right)=\mathrm{X}_{\mathrm{i}}^{\mathrm{w}} \beta+\mathrm{E}\left(\varepsilon_{\mathrm{i}}^{\mathrm{w}} \mid \varepsilon_{\mathrm{i}}^{\mathrm{empl}}>-\mathrm{X}_{\mathrm{i}}^{\mathrm{empl}} \alpha\right)
$$

By estimating

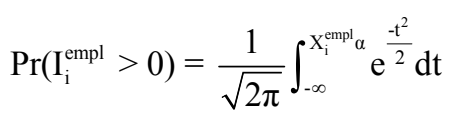

and assuming that $\mathrm{X}_{\mathrm{i}}\left(\varepsilon_{\mathrm{i}}{ }^{\mathrm{W}}, \varepsilon_{\mathrm{i}}{ }^{\mathrm{empl}}\right)$ is a bivariate normal density one can estimate the last term on the right-hand side of the general wage equation:

$$
\mathrm{E}\left(\varepsilon_{\mathrm{i}}^{\mathrm{w}} \mid \varepsilon_{\mathrm{i}}^{\mathrm{empl}}>-\mathrm{X}_{\mathrm{i}}^{\mathrm{empl}} \alpha\right)=\left(\delta^{\mathrm{w}, \mathrm{empl}} / \delta^{\mathrm{empl}}\right) \lambda_{\mathrm{i}}
$$

and the sample selection correction term (the inverse of Mill's ratio) can be computed as:

$$
\lambda_{\mathrm{i}}=\phi\left(\mathrm{X}_{\mathrm{i}}^{\mathrm{empl}} \alpha / \delta^{\mathrm{empl}}\right) / \Phi\left(\mathrm{X}_{\mathrm{i}}^{\mathrm{empl}} \alpha / \delta^{\mathrm{empl}}\right)
$$

where $\phi$ and $\Phi$ are, respectively, the density and distribution function for a standard normal variable. Thus, the actual model of the wage will now become:

$$
\log \left(\mathrm{w}_{\mathrm{i}}\right)=\mathrm{X}_{\mathrm{i}}^{\mathrm{w}} \beta+\left(\delta^{\mathrm{w}, \mathrm{empl}} / \delta^{\mathrm{empl}}\right) \lambda_{\mathrm{i}}+v_{\mathrm{i}}
$$

\section{Resolving Simultaneity Bias}

The wage rate exogeneity assumption usually induces upward sloping bias in estimated wage elasticities (Mroz, 1987), as there are some important unobserved individual effects which are correlated with explanatory variables in the individual labour supply equation. Consequently, the wage appearing as an endogenous 
explanatory variable in this equation may become stochastic. The lack of control over possible model misspecification leads to the violation of the orthogonality and sphericality assumptions in the regression framework, which results in asymptotically inconsistent estimates (Hausman, 1978). To resolve the simultaneity bias we instrument the selection bias corrected model based on the variable set $\mathrm{X}^{\mathrm{w}}$. Note, that the used instrument is of exceptionally high quality $\left(\mathrm{R}^{2}=0.92\right)$ and the inconsistencies present in IV regression with weak instruments are unlikely to occur (Staiger \& Stock, 1997).

\section{The Probabilistic Models of Participation}

The analysis of labour force states comprises two dichotomous dependent variable models. First, the probability of participating conditional on ability to work ${ }^{1}$ is estimated by means of a probabilistic model. To motivate the Probit model, we assume that any given person compares utility if participating, with utility if outside the labour force. Let $\mathrm{I}_{\mathrm{i}}^{\mathrm{PA}}$ be an indicator of labour force status, so that $\mathrm{I}_{\mathrm{i}}^{\mathrm{PA}}>0$ if an individual is either employed or unemployed and $\mathrm{I}_{\mathrm{i}}^{\mathrm{PA}} \leq 0$ if he remains out of the labour force. Consequently, the probability of participating, given one is able to work, can be described as:

$$
\operatorname{Pr}\left(\mathrm{P}_{\mathrm{i}} \mid \mathrm{A}_{\mathrm{i}}\right)=\operatorname{Pr}\left(\mathrm{I}_{\mathrm{i}}^{\mathrm{PA}}=\mathrm{X}_{\mathrm{i}}^{\mathrm{PA}} \gamma+\mathrm{e}_{\mathrm{i}}^{\mathrm{PA}}>0\right)=\operatorname{Pr}\left(\mathrm{e}_{\mathrm{i}}^{\mathrm{PA}}>-\mathrm{X}_{\mathrm{i}}^{\mathrm{PA}} \gamma\right)=\mathrm{F}^{\mathrm{PA}}\left(-\mathrm{X}_{\mathrm{i}}^{\mathrm{PA}} \gamma\right)
$$

where $\mathrm{X}_{\mathrm{i}}^{\mathrm{PA}}$ is a vector of variables determining participation such as logarithmic wage, regional unemployment rate, marital status, non-labour income, etc., and $\mathrm{F}^{\mathrm{PA}}$ is the normal probability density function.

Then, we turn to probability of employment conditional upon participation:

$$
\operatorname{Pr}\left(E_{i} \mid P_{i}\right)=\operatorname{Pr}\left(I_{i}^{E P}>0\right)=\operatorname{Pr}\left(e_{i}^{E P}>-X_{i}^{E P} \phi\right)=F^{E P}\left(-X_{i}^{E P} \varphi\right)
$$

In this particular model $\mathrm{X}_{\mathrm{i}}^{\mathrm{EP}}=\mathrm{X}_{\mathrm{i}}^{\mathrm{PA}}$. Having estimated $\log \left(\mathrm{w}_{\mathrm{i}}\right), \mathrm{F}^{\mathrm{PA}}$, and $\mathrm{F}^{\mathrm{EP}}$, the probability of an individual being employed, given he is able to work, can be computed:

$$
\operatorname{Pr}\left(E_{i} \mid A_{i}\right)=\operatorname{Pr}\left(P_{i} \mid A_{i}\right) * \operatorname{Pr}\left(E_{i} \mid P_{i}\right)=F^{P A}\left(-X_{i}^{P A} \gamma\right)^{*} F^{E P}\left(-X_{i}^{E P} \varphi\right)
$$

since all the values on the right-hand side of the above relationship are known.

\section{The Model of Hours of Work Supplied Weekly}

Finally, we focus on a labour supply model of functional form similar to those frequently found in the literature. Nonetheless, it is quite unique, as it incorporates variables not present in previous studies.

$$
\log \left(\mathrm{h}_{\mathrm{i}}\right)=\delta_{1}+\delta_{2} \log \left(\mathrm{w}_{\mathrm{i}}\right)+\delta_{3} \log \left(\mathrm{HH}_{\mathrm{i}}\right)+\delta_{4} \mathrm{NLI}_{\mathrm{i}}+\delta_{5} \mathrm{MS}_{\mathrm{i}}+\delta_{6} \mathrm{Sex}_{\mathrm{i}}+\delta_{7} \mathrm{Party}_{\mathrm{i}}+\delta_{7} \mathrm{OTQ}_{\mathrm{i}}+\varepsilon_{\mathrm{i}}^{\mathrm{h}}=\mathrm{Z}_{\mathrm{i}}^{\mathrm{h}} \delta
$$

where $\log \left(\mathrm{h}_{\mathrm{i}}\right)$ is the individual's logarithmic hours of work supplied per week, including overtime, $\mathrm{w}_{\mathrm{i}}$ is a measure of self-selection corrected instrumented wage, $\mathrm{HH}_{\mathrm{i}}$ is the number of hours spend on housework weekly, $\mathrm{NLI}_{\mathrm{i}}$ is non-labour income per month in thousands of pounds, $\mathrm{MS}_{\mathrm{i}}$ stands for marital status(1 if married), Sex is a gender dummy ( 1 for male), Party $y_{i}$ is a vector of binomial variables describing individual's political preferences, $\mathrm{OTQ}_{\mathrm{i}}$ is a vector of continuous variables representing quantified responses to opinion type questions (scale 1-10), and $\varepsilon_{\mathrm{i}}^{\mathrm{h}}$ is a stochastic disturbance.

\section{Data Set and Sample Characteristics}

The data set used for our study is from the British Household Panel Survey (BHPS) downloaded from the Essex data archive. It is a nationally representative sample across Great Britain, consisting of around 5,500 households. The panel started in 1991 and the first wave of interviews included 13,840 individuals. The same individuals were contacted, as far as possible, for the subsequent waves of the survey. We use Wave 8 of the

\footnotetext{
${ }^{1}$ An individual is able to work if he belongs to the adult population and is neither retired nor disabled.
} 
BHPS survey (1997). We extract the data from the Hindresp file, which comprises of detailed information on opinions and socio-economic values of 10,300 respondents. The BHPS is an extremely rich source of data that provides almost every piece of information relevant to the labour market and also on the individual's labour supply (Taylor, Brice, Buck, \& Lane, 1999). The data set has been extended to include the ONS 1997 data on regional unemployment rates ${ }^{2}$.

The variable collection included by the model is quite unique, as it not only embodies the standard variables utilised by other studies, but also the quantified responses to the opinion-type questions (priorities in life and political views). We conclude that these variables have a significant impact on the individual's labour supply and therefore should not be overlooked. There is however one transparent issue related to usage of these variables, namely, the lack of normalisation techniques due to their subjective nature. Consequently, one is only interested in the sign and statistical significance, rather than in the nominal value of their coefficients.

This research focuses on wages and labour market supply, and thus specific features of these variables are of particular interest. The frequency distribution of the gross wage rates in the sub-sample of individuals in paid employment is plotted on Figure 1 below. Some descriptive statistics related to this distribution are given in Table 1.

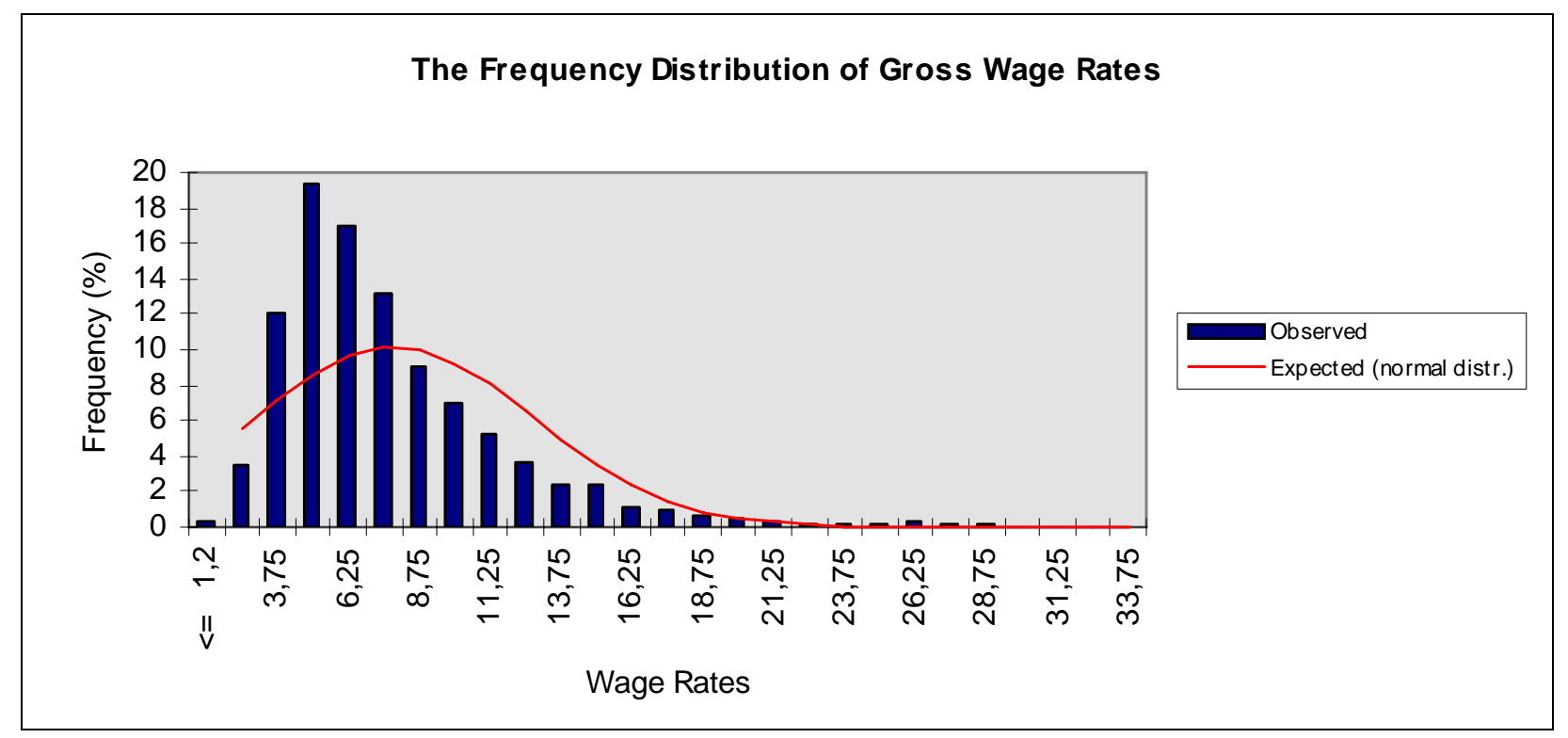

Figure 1. The frequency of distribution of gross wage rates.

Table 1

Wage Statistics

\begin{tabular}{lllll}
\hline & Mean & Median & Skewness & Kurtosis \\
\hline Value & 7.254337 & 6.048609 & 5.287337 & 73.23747 \\
S.E. & $(4.890517)$ & & $(0.034266)$ & $(0.068519)$ \\
\hline
\end{tabular}

Note. All values in pounds per hour. Source: Own computations.

The gross wage rate distribution is asymmetric. It is considerably skewed to the right and the median does not coincide with the mean. This result may indicate a smaller number of people have productivity levels above the average. Moreover, the considered distribution is leptokurtic, which is fully consistent with longstanding

\footnotetext{
${ }^{2}$ Wisniewski, D. (Ed.). (1997). Monthly Digest of Statistics (No. 624). Office for National Statistics. Dec. 1997.
} 
evidence for Britain (Lydall, 1968).

The classification of individuals with respect to their current labour force status is demonstrated in Table 2. Given that all survey participants reached the age of 16 , there is no strong basis to question the representative character of the sample.

Table 2

Labour Force Status

\begin{tabular}{lll}
\hline Labour force status & Frequency & Percentage of the sample \\
\hline Employed & 5,108 & $46.8 \%$ \\
Unemployed & 372 & $3.4 \%$ \\
Out of labour force, but able to work & 2,460 & $22.6 \%$ \\
Retired, disabled, unable to work & 2,810 & $25.8 \%$ \\
Total valid cases & 10,750 & $98.6 \%$ \\
Missing cases & 156 & $1.4 \%$ \\
Sample size & 10,906 & $100 \%$ \\
\hline
\end{tabular}

Source: Own derivations.

As one can clearly see on the following diagram (Figure 2), there are some significant discrepancies if the frequency distribution of hours worked per week, including overtime and the expected values under the normal distribution were to be compared.

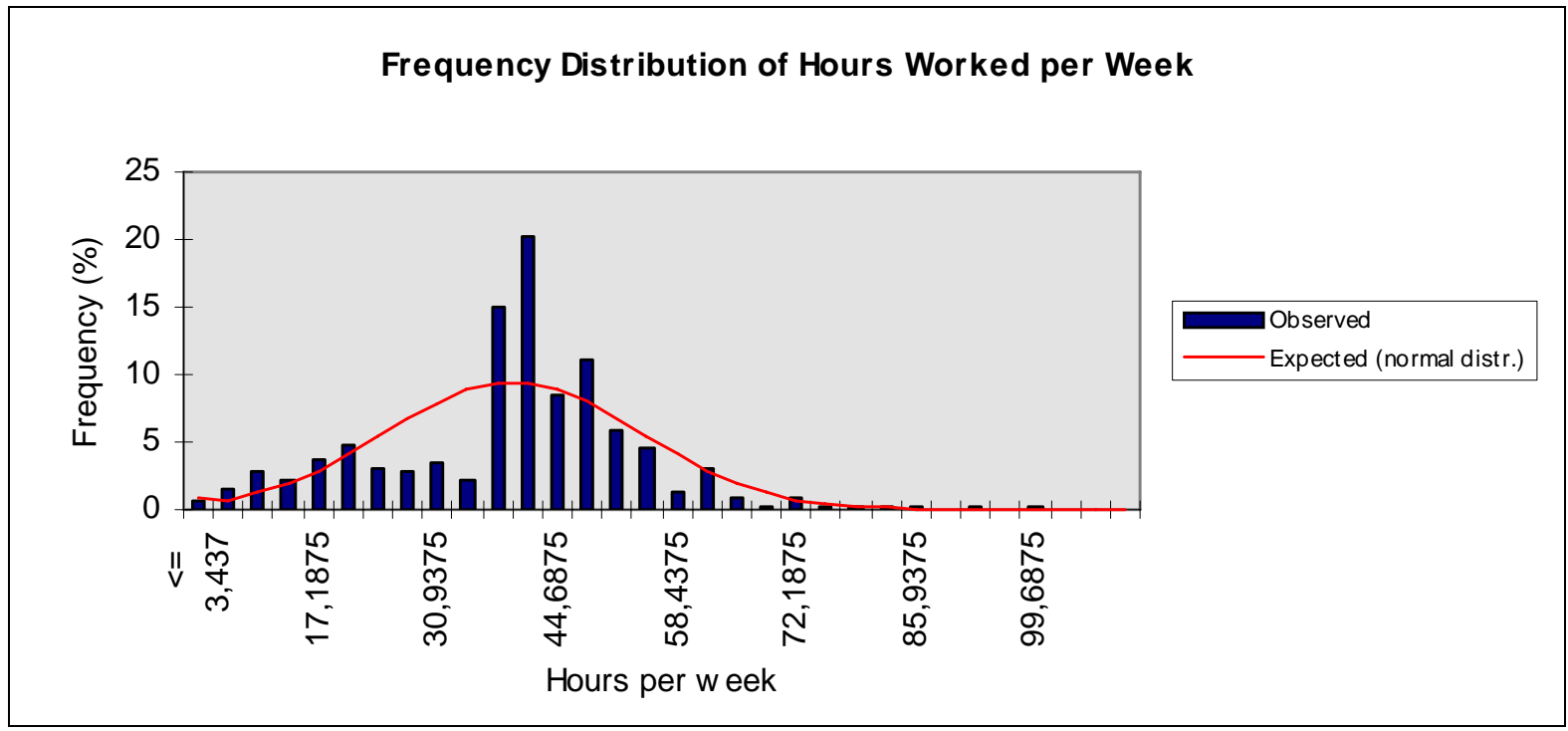

Figure 2. Frequency distribution of hours worked per week.

In the sub-sample of employed individuals there is a notable concentration of observations around values of 20 (half-time job) and 40 (full-time job). This reflects rigidities and constraints on the labour demand side, which are not explicitly considered in this research due to limitations of the data set. As a result, one can expect the hours of labour supplied model to have relatively low explanatory power. Not surprisingly, we find that a low coefficient of determination is a common feature of all empirical models of hours of labour supplied.

\section{Empirical Results on Determinants of Wages and Labour Supply}

We present and discuss empirical results that derived from the survey data in this section. The estimated 
coefficients reflecting the relative importance of various factors in determining wages and labour supply among individuals are given in Table 3 .

\section{The Wage Inequalities}

We start with regressing the wage equation (1) using the ordinary least squares method on the sub-sample of interviewed workers.

Table 3

The Wage Model Estimates

\begin{tabular}{|c|c|c|c|}
\hline Variable & Coefficient & T-stat. & Mean \\
\hline Intercept & 0.042865 & 0.2773 & \\
\hline Years of schooling (derived variable) & 0.041662 & 14.2672 & 12.136 \\
\hline Age at date of interview & 0.059554 & 21.3142 & 36.662 \\
\hline Age squared & -0.000650 & -18.3420 & 1492.846 \\
\hline Vocational qualifications & 0.042175 & 3.3939 & 0.389 \\
\hline Sex & 0.223546 & 18.1097 & 0.500 \\
\hline English as second language & -0.222350 & -2.7740 & 0.025 \\
\hline \multicolumn{4}{|l|}{ RG Social Class (most recent job): } \\
\hline Professional occupation & 0.162362 & 0.7498 & 0.073 \\
\hline Managerial and technical & 0.073698 & 0.3422 & 0.304 \\
\hline Skilled non-manual & -0.210799 & -0.9770 & 0.288 \\
\hline Skilled manual & -0.264472 & -1.2254 & 0.205 \\
\hline Partly skilled occupation & -0.360438 & -1.6732 & 0.177 \\
\hline Unskilled occupation & -0.424298 & -1.9709 & 0.069 \\
\hline Armed forces & 0.113362 & 0.4318 & 0.020 \\
\hline \multicolumn{4}{|l|}{ Region/Metropolitan Area Dummies: } \\
\hline Inner London & 0.289657 & 3.4308 & 0.048 \\
\hline Outer London & 0.252697 & 3.1381 & 0.080 \\
\hline R. of South East & 0.155620 & 1.9941 & 0.219 \\
\hline South West & 0.083689 & 1.0566 & 0.112 \\
\hline East Anglia & 0.046243 & 0.5614 & 0.058 \\
\hline East Midlands & 0.013843 & 0.1746 & 0.110 \\
\hline West Midlands Conurb. & 0.061383 & 0.7387 & 0.054 \\
\hline R. of West Midlands & 0.045400 & 0.5634 & 0.078 \\
\hline Greater Manchester & 0.151121 & 1.8403 & 0.060 \\
\hline Merseyside & 0.153563 & 1.7593 & 0.039 \\
\hline R. of North West & 0.090306 & 1.1025 & 0.062 \\
\hline South Yorkshire & 0.070065 & 0.8220 & 0.044 \\
\hline West Yorkshire & 0.050060 & 0.5990 & 0.051 \\
\hline R. of Yorks \& Humber & 0.032916 & 0.3931 & 0.050 \\
\hline Tyne \& Wear & 0.051728 & 0.6001 & 0.042 \\
\hline R. of North & 0.035033 & 0.4255 & 0.059 \\
\hline Wales & 0.051493 & 0.6336 & 0.068 \\
\hline Scotland & 0.106978 & 1.3404 & 0.094 \\
\hline Northern Ireland & 0.024426 & 0.2779 & 0.038 \\
\hline $\mathrm{R}^{2}=0.92273928$, Adjusted $\mathrm{R}^{2}=0.922$ & & & \\
\hline
\end{tabular}

Notes. Dependent variable: log gross hourly earnings (derived variable); Number of observations: 5,108; Mean of dependent variable is 1.8226 . 
Years of schooling derived from information on the highest completed educational degree or vocational degree by attaching an average number of years to standardised educational levels. This variable proxies human capital acquired through formal education. Because the regression is estimated with log wages the coefficient $\beta_{1}$ has a very useful property. Therefore, in absence of ability bias, it can be interpreted as an estimate of the rate of return to schooling for population $\mathrm{j}, \beta_{1}=\Delta\left(\log \mathrm{w}_{\mathrm{i}}\right) / \Delta \mathrm{s}_{\mathrm{i}} \approx \% \Delta \mathrm{w}_{\mathrm{i}} / \Delta \mathrm{s}_{\mathrm{i}}$. In practice, however, the correlation between schooling and earnings is contaminated by the presence of unobserved ability. Most studies estimating the rate of return to education fail to control for the effects of ability bias, which usually results in overstating the real returns. In recent years some attempts have been made to resolve this problem, including IQ scores (Clark \& Trash, 1987; Card, 1994; Blackburn \& Neumark, 1992) or results of technical tests (Blackburn \& Neumark, 1993) in earnings equations. Nonetheless these variables tend to be highly correlated with the level of schooling, which leads to colinearity problems, with large sampling variances and spurious regressors (for more details see Griliches, 1977). Unfortunately, BHPS does not include any non-academic proxies for ability. The estimated rate of return to schooling includes an upward sloping bias. Nonetheless, the value of 4.166 percent seems to be relatively low compared with commercial interest rates offered by financial institutions in the considered time period. The spot rate on 10 year government bonds oscillated in 1997 around 7\%. This may be an indication that the general non-vocational training outside the workplace (i.e. schooling) is not as good investment as it is perceived to be. On the other hand, the considered estimate indicates only rate of return to one year of schooling. The cumulative effect is much stronger (Psacharopoulos, 1985).

The quadratic specification in terms of age allows us to capture the concavity of age-earning profiles. Murphy and Welch (1990) show that extending this specification, by adding higher-order terms in experience, could reduce the serial autocorrelation of regression residuals and lessen mean squared bias. Nonetheless, the quadratic form is the widely accepted empirical specification, which approximates actual growth of earnings over the career. Moreover it enables us to evaluate almost effortlessly the peaks of age-earnings profiles, as follows:

$$
\Delta\left(\log \mathrm{w}_{\mathrm{i}, \mathrm{j}} / \Delta \mathrm{E}_{\mathrm{i}, \mathrm{j}}=0 \Rightarrow \text { (peak of the age earning profile }\right)_{\mathrm{j}}=-\beta_{2, \mathrm{j}} / 2 \beta_{3, \mathrm{j}}
$$

Most of empirical studies based on quadratic functions suggest that average earnings profiles peak around 30 years of labour market experience (Mincer, 1974; Green, 1998). We find that the logarithmic wage rate reaches its maximum at about 45.8 years of age, which is comparable with earlier findings in the literature.

We include vocational qualification variables following Arulampalam and Booth (1998). With NCDS survey data they show that it is only training incidence that matters for the wage growth, and not the number of courses. Inclusion of a specific training variable permits us to isolate the returns to on-the-job investments. Failure to do so can result in overestimation of the returns to initial human capital investments such as schooling. We find the coefficient of the training binomial variable to be 0.042175 . This corresponds to a potential enlargement of the wage rate for individuals completing on-the-job training for the first time by about $4.3077 \%(=[\exp (0.042175)-1] * 100)$.

The size and statistical significance of the sex-related wage gap at first glance seem somewhat controversial. Men earned on average 25 percent more than women. But in fact, the male wage premium is even larger in some other European countries. For instance, the study by Lauer (2000) estimates the gender wage gap in West Germany to be in order of $36.1 \%$. The inferiority of female wages is often attributed to career interruptions for family reasons. These breaks in career result in loss of on-the-job training and difference in 
labour market experiences (Gronau, 1988; Connolly, 1997; Carlson \& Wartz, 1998; Chinhui \& Murphy, 1997). Part of the gap could be also explained by occupational segregation. The female labour force is often seen crowding into lower paid occupations.

As might be expected language fluency has a role to play in describing differences in the log wage rates. Relative to these who are classified as speaking English fluently, there is an approximate 24.9 percent earnings penalty from having inferior language skills. This is an equivalent of the gender gap. Not only are foreigners earning less but, as we will show later, they are less likely to find a job. Our estimate however, seems to be relatively exaggerated compared to other studies (O'Leary, Murphy, Drinkwater, \& Blackaby, 1999), which could be a consequence of under-representation of the considered group in the sample (only 88 valid cases).

Our results on earning differences across social class are consistent with common sense. Highest wage rate has been observed for professionals and the lowest one for unskilled workers.

We also observe a meaningful variation of wage rates across various regions within the Great Britain. Premiums on wages in inner London, outer London, and the rest of the South East are 33.6 percent, 28.7 percent, and 16.8 percent respectively and are subject to great statistical significance. This may be a strong basis to question the perfectly competitive character of the UK labour market, where individuals with similar labour market characteristics differ in their wage rates across the regions. It is, however, not a direct negation of the microeconomic theory, which says that the wage rate should be equalised with value of the marginal product of labour. Note that the production process in large agglomerations such as London or Manchester, tends to be more capital intensive and, consequently, average productivity per worker may be higher in these regions.

\section{Implications of Self-selection Adjustments}

The BHPS includes data on expected wages for the sub-sample of unemployed people. Each individual, who was actively looking for a job, was asked on his prediction concerning net wage once employed. This information proves to be very useful in the context of this research, since this allows us to determine if the unemployment spell is a result of excessive wage demands.

Table 4

Do Job-Seekers Have Overoptimistic Wage Expectations?

\begin{tabular}{llll}
\hline & $\begin{array}{l}\text { Expected net wage rate: } \\
\text { job-seeker (derived variable) }\end{array}$ & $\begin{array}{l}\text { Net wage rate prediction based } \\
\text { on the wage model }\end{array}$ & $\begin{array}{l}\text { Gross wage rate prediction } \\
\text { based on the wage model }\end{array}$ \\
\hline Average & 5.124557 & 3.642086 & 5.193973 \\
Standard deviation & 3.74482 & 1.256836 & 1.792373 \\
\hline
\end{tabular}

Note. Number of observations: 694.

Unemployment seems to overestimate the market value of their labour supply by about $28.9 \%$. Although the gap is rather sizeable, it is not statistically significant. Furthermore, it can be inferred from the data presented in Table 4, in the absence of tax and national insurance deductions, an average job-seeker would be willing to undertake any job at going market wage. This empirical result vividly highlights the beneficial implications of personal income tax cuts for the labour market.

It is apparent that the minimum expected wage rate could be a good proxy for the individual's reservation wage. Modelling such a proxy, or for instance investigating the relationship between excess wage demands and non-labour income should provide some insights onto the trends in unemployment rates. This is quite a 
profound macroeconomic issue demanding further study. We do not intend to analyse it further within this paper. The idea, however, has been clearly identified. Its empirical implementation may follow in the near future.

Another intriguing question that can be investigated at this stage is the size of the gap between wage rates of salaried workers and potential wage rates of non-working individuals. Some descriptive statistics relating to this issue are provided in Table 5 below:

Table 5

Differences in Wages Predicted by the Model (in Pounds per Hour)

\begin{tabular}{llll}
\hline & Not working & In paid employment & Whole sample \\
\hline Average & 5.8630 & 7.2543 & 6.7580 \\
Standard deviation & 3.7365 & 4.8905 & 4.4307 \\
Number of cases & 2,832 & 5,108 & 7,940 \\
\hline
\end{tabular}

Source: Own computations.

The difference in gross earnings is as big as $£ 1.39$ per hour. The magnitude of this discrepancy can be explained solely on the basis of the presented wage model. Therefore, the gap directly quantifies the inferiority of labour market characteristics of the non-working people.

\section{The Probabilistic Models of Participation and Employment}

Tables 6, 7, 8, and 9 below show results of the Probit analysis on participation in the labour market and employability of individuals already in the labour force. From these one can evaluate the effect of each variable on participation and the statistical significance of the considered effects. We first model the probability of participating given that one is able to work, and then turn to the chance of being employed once in the labour force.

Table 6

Binomial Probit Model (Probability of Participating Given One Is Able to Work)

\begin{tabular}{ll}
\hline Dependent variable & Participation \\
\hline Log likelihood function & -4546.511 \\
Restricted log likelihood & -4929.650 \\
Chi-squared & 766.2786 \\
Degrees of freedom & 13 \\
\hline
\end{tabular}

Table 7

Index Function for Probability of Participation

\begin{tabular}{lllll}
\hline Variable & Coefficient & S.E. & T-stat. & Mean of X \\
\hline Constant & 0.418731464 & 0.1901692 & 2.202 & 1.7627939 \\
Log wage prediction & 0.116349221 & 0.04553701 & 2.555 & 0.0491741 \\
Regional unemployment rate & -0.207060363 & 1.1195939 & -0.185 & 10.276700 \\
Number of hours spent on housework weekly & -0.013544027 & 0.00148667 & -9.110 & 0.1250598 \\
Non labour income & -0.330800310 & 0.04175484 & -7.922 & 0.5536524 \\
Married & -0.220534631 & 0.03363379 & -6.557 & 0.0073048 \\
English as second language & -0.417421848 & 0.17673205 & -2.362 & \\
Political Party Supported & & & & \\
\hline
\end{tabular}

\footnotetext{
${ }^{3}$ In thousands of pounds per month.
} 
Table 7 to be continued

\begin{tabular}{lllll}
\hline Conservative & 0.075383701 & 0.04406321 & 1.711 & 0.2001259 \\
Labour & 0.297454132 & 0.03730073 & 7.974 & 0.3853904 \\
Liberal & 0.319887760 & 0.05612258 & 5.700 & 0.1055416 \\
Opinion Type Questions: & & & & 9.556297 \\
Importance of health & -0.1042378013 & 0.01629281 & -6.398 & 6.421663 \\
Importance of money & 0.0216673532 & 0.00751327 & 2.884 & 7.416625 \\
Importance of having children & -0.0028306233 & 0.00573860 & -0.493 & 7.948363 \\
Importance of job & 0.1165666351 & 0.00754271 & 15.454 & \\
\hline & & & & Total \\
\hline Actual & Predicted & & 2,479 \\
\hline (inactive) & 0 (inactive) & 1 (active) & 5,461 \\
1 (active) & 599 & 1,880 & & 7,940 \\
Total & 255 & 5,206 & & \\
\hline
\end{tabular}

Table 8

Binomial Probit Model (Probability of Working Given Participation)

\begin{tabular}{ll}
\hline Dependent variable & Working \\
\hline Log likelihood function & -1212.949 \\
Restricted log likelihood & -1310.846 \\
Chi-squared & 195.7940 \\
Degrees of freedom & 13 \\
\hline
\end{tabular}

Table 9

Index Function for Probability of Working

\begin{tabular}{|c|c|c|c|c|}
\hline Variable & Coefficient & S.E. & T-stat. & Mean of X \\
\hline Constant & 0.639934446 & 0.0502601 & 2.098 & \\
\hline Log wage prediction & 0.278144375 & 0.0856109 & 3.249 & 1.7772919 \\
\hline Regional unemployment rate & -3.94215054 & 1.9783359 & -1.993 & 0.0491033 \\
\hline Number of hours spent on housework weekly & -0.01186706 & 0.0029044 & -4.086 & 9.0640908 \\
\hline Non labour income & -0.56294295 & 0.1053335 & -5.344 & 0.0987165 \\
\hline Married & 0.43437977 & 0.6317260 & 6.876 & 0.5209668 \\
\hline English second language & -0.27864439 & 0.3193311 & -0.873 & 0.0054935 \\
\hline \multicolumn{5}{|l|}{ Political Party Supported: } \\
\hline Conservative & 0.459919204 & 0.09366788 & 4.910 & 0.1931881 \\
\hline Labour & 0.192511218 & 0.06391944 & 3.012 & 0.4110969 \\
\hline Liberal & 0.126366160 & 0.09646776 & 1.310 & 0.1146310 \\
\hline \multicolumn{5}{|l|}{ Opinion Type Questions: } \\
\hline Importance of health & 0.0369572972 & 0.02471114 & 1.496 & 9.5061344 \\
\hline Importance of money & -0.0190702752 & 0.01339131 & -1.424 & 6.5222487 \\
\hline Importance of having children & 0.0156779815 & 0.01000925 & 1.566 & 7.3479216 \\
\hline \multirow[t]{2}{*}{ Importance of job } & 0.0115251396 & 0.01613746 & 0.714 & 8.2506867 \\
\hline & \multicolumn{4}{|l|}{ Predicted } \\
\hline Actual & 0 (inactive) & \multicolumn{2}{|l|}{1 (active) } & Total \\
\hline 0 (inactive) & 353 & \multicolumn{2}{|l|}{1} & 354 \\
\hline 1 (active) & 1 & \multicolumn{2}{|l|}{5,106} & 5107 \\
\hline Total & 354 & \multicolumn{2}{|l|}{5107} & 5461 \\
\hline
\end{tabular}


The estimates in Table 7 could be extremely useful to forecast the future size of the labour force out of working age population. They could also be used to evaluate work incentives created by a given fiscal policy. Regression results from the second Probit function provide some microeconomic insights onto determinants of level of unemployment.

Results of these models show that the income effect of wage improvements was outweighed by the positive substitution effect for participation. These findings indicate that a $10 \%$ increase in the wage rate should be followed by a 1.16 percentage point growth in the participation. The regressor representing hours spent on housework weekly can, to certain extent, reflect the magnitude of fixed costs of employment. It is a very important factor influencing labour supply decisions, especially in the context of married couples (Cho \& Rogerson, 1988; Lauer \& Steiner, 2000). The more hours they spend on household work, the less likely they are to participate in the labour market. Its significant and negative impact is confirmed in the reported estimates.

The effect on the willingness to work of people who vote for the three biggest political parties seems to be much larger compared with the rest of the society. No simple normative story can be told in order to explain this result. The supporters of the Conservative Party are less likely to participate than individuals associating themselves with the Labour and Liberal Democrat Parties. Moreover they tend to supply less hours of labour. Nonetheless, it is relatively easy for them to find a job once they participate in the labour force.

Interestingly, we find that the psychological profile of an individual has a very big influence over the decision on whether to participate. However once he joined the labour force his personal beliefs and opinions have no impact on probability of finding a job. The chance of being employed once participating depends mainly on the local labour market conditions (the unemployment rate regressor becomes statistically significant in the second Probit model $\left.\operatorname{Pr}\left(\mathrm{E}_{\mathrm{i}} \mid \mathrm{P}_{\mathrm{i}}\right)\right)$. This unique result is somewhat not surprising and seems to conform to common sense intuition. Considering an individual that gets a higher utility level once employed and at the same time is not participating, he will have nothing to lose if he joins the labour force, but the chance of finding an employer depends mostly on his labour market characteristics. Observable variables such as education and years of experience send the clearest and the strongest signal to the employer during selection procedure. On the other hand, perceptual and psychological notions can be easily misrepresented at the time of the job interview. It takes time for the companies to learn the true productivity, ability, and commitment of the hired agents. It becomes expensive to cancel the work contract by the time they know the employee. For this reason, an under-performing employee faces poor promotion perspectives rather than a dismissal. Consequently, we do not observe a significant relationship between $\operatorname{Pr}\left(\mathrm{E}_{\mathrm{i}} \mid \mathrm{P}_{\mathrm{i}}\right)$ and the continuous opinion-type variables.

\section{Estimating the Labour Supply Elasticity and Hours of Work Equation}

Now we turn to analysing the hours of work of participants. The OLS estimates of hours of work equation (2) are presented below. These results indicate hours of working people would like to supply as a function of individual specific variables.

The logarithmic specification that we have used provides direct estimate of the wage elasticity of hours of work. Our estimates indicate that the substitution effect of an increase in the wage rate dominates the income effect. For instance a one percent rise in the gross wage generates a $0.174 \%$ increase in hours of labour supplied. For employed individuals, one would expect the elasticity to be much greater compared with the sample we have quoted. Therefore, we also undertake the necessary steps to obtain the elasticity estimate for the group of 
people in paid employment. Its value appears to be 0.295 , which confirms the intuition and theory. Until recently the common opinion among labour economists was that the aggregate labour supply curve was negatively sloped. However, the latest evidence has begun to cast doubts on the slope of the overall labour supply curve (for literature review see Elliott, 1990; Killingsworth, 1983). Broadly speaking, our findings on the elasticities are comparable with these reported in the nineties.

Table 10

The Hours of Labour Supplied Model

\begin{tabular}{|c|c|c|c|}
\hline & & Unrestricted & Model \\
\hline Variable & Beta & T-value & Mean $^{\mathrm{u}}$ \\
\hline Intercept & 0.672 & 7.791 & \\
\hline Log wage & 0.174 & 14.706 & 1.77516 \\
\hline Log hours per week on housework & -0.197 & -15.328 & 1.01233 \\
\hline Non-labour income per month ${ }^{4}$ & -0.178 & -16.833 & 0.13764 \\
\hline Marital status & -0.031 & -2.747 & 0.56618 \\
\hline Sex & -0.041 & -3.077 & 0.48168 \\
\hline \multicolumn{4}{|l|}{ Political Party Supported: } \\
\hline Conservative & -0.015 & -1.188 & 0.21269 \\
\hline Labour & 0.038 & 3.047 & 0.39793 \\
\hline Lib Dem/Lib/SDP & 0.009 & 0.771 & 0.11812 \\
\hline \multicolumn{4}{|l|}{ Opinion Type Questions: } \\
\hline Importance of health & -0.024 & -2.293 & 9.56769 \\
\hline Importance of money & 0.013 & 1.186 & 6.43345 \\
\hline Importance of having children & -0.049 & -4.303 & 7.42828 \\
\hline Importance of having a good job & 0.137 & 12.538 & 7.95995 \\
\hline Mean of dependent var. & 3.318277 & & \\
\hline No. of observations & 7940 & Adjusted $\mathrm{R}^{2}$ & 0.141 \\
\hline
\end{tabular}

Note. Dependent variable: log hours worked per week, including overtime.

Other economic variables included in the equation (2) seem to have the expected direction of impact. Married women tend to supply fewer hours of labour, despite persistence of a strong upward sloping trend in their participation rates. This has been a very prominent labour market feature in the post-war period (Goldin, 1989; Layard, Barton, \& Zabalza, 1980). Single men, on the other hand, are not very keen on housework, but seem to be very devoted to their paid job.

The magnitude of initial endowment (non-labour income) has an enormously significant influence on the labour supply decision. This follows from basic microeconomic principles. Once again, we infer that personal beliefs and political alliances can be important factors in labour supply decision-making process as is the participation decision.

\section{Conclusions}

We have explained a big proportion of the differences in wages and labour supply among British individuals. Not only have we considered a wide range of economic characteristics, but also made an attempt to describe individuals' personal profile by means of additional regressors relating to motivation toward work and political affiliations. This allowed us to illustrate the labour market response of working individuals in the

\footnotetext{
${ }^{4}$ In thousands pounds.
} 
economy. These variables help describe the labour supply decision-making process more accurately at a micro level. The estimates reported in this study are free of biases, since we control for self-selection into the labour force and relax the exogeneity assumption on the wage rate. The conclusions reached in this research are, in general, similar compared with these derived from many studies in the late 1990's.

\section{Acknowledgement}

I appreciate the Social Science Faculty of the Hull University for the research grant \#500R054. I am also grateful to the University of Essex for providing us an access to the BHPS data set in the Essex data archive through MIMAS. I acknowledge valuable research assistantship provided by Tomasz Wisniewski who was the topmost student in BSc (econ) degree in year 2000. I acknowledge R. J. Green, W. Polasek, G. Pelloni, and participants of summer 2000 econometrics conference under the Centre for Economic Policy at Hull for comments and suggestions. All errors and omissions are of my own.

\section{References}

Angrist, J. D. (1991). Grouped-data estimation and testing simple labour supply models. Journal of Econometrics, 47, $243-266$.

Arulampalam, W. N., \& Booth, A. L. (1998). Learning and earning: Do multiple training events pay? A decade of evidence from a cohort of young British men. Economica, 68(271), 379-400.

Bhattarai, K., \& Wisnieski, T. (2000). Determinants of wages and labour supply in the UK. Hull Economics Research Paper no. 277.

Bhattarai, K., \& Whalley, J. (1999). Role of labour demand elasticities in tax incidence analysis with heterogeneous labour. Empirical Economics, 24(4), 599-619.

Blackburn, M. K., \& Neumark, D. (1993). Omitted-ability bias as the increase in the rate of schooling. Journal of Labour Economics, 11(3), 521-544.

Blackburn, M. K., \& Neumark, D. (1992). Unobserved ability, efficiency wages, and interindustry wage differentials. Quarterly Journal of Economics, 107, 1421-1436.

Blundell, R., Duncan, A., \& Meghir, C. (1992). Empirical labour supply models: Lone mothers in the UK. Economic Journal, 102(411).

Card, D. (1994). Schooling, ability and earnings revisited. NEBR Working Paper, 4832.

Carlson, L. A., \& Swartz, C. (1988). The earnings of women and ethnic minorities, 1959-79. Industrial and Labor Relations Review, 41, 530-546.

Chinhui, J., \& Murphy, K. M. (1997). Wage inequality and family labour supply. Journal of Labour Economics, 15(1), 72-97.

Clark, A., \& Trash, J. (1987). How much is a degree worth? Audit, 109-115.

Connolly, S. (1997). A model of female labour supply in which supply is dependent upon the chances of finding a job. Applied Economics, 29, 1379-1386.

Chrisitiano, L. J., \& Eichenbaum, M. (1992). Current real business cycle theories and aggregate labour-market fluctuation. American Economic Review, 82, 430-450.

Cho, J., \& Rogerson, R. (1988). Family labour supply and aggregate fluctuations. Journal of Monetary Economics, 21, 233-245.

Dex, S., Clark, A., \& Taylor, M. (1995). Household labour supply. Research Series (Great Britain. Department of Employment), No. 43). Sheffield, England: Employment Dept.

Dickens, R. (2000). The evolution of individual male earnings in Great Britan: 1975-95. Economic Journal, 110, $27-49$.

Dougherty, C. R. S., \& Jimenez, E. (1991). The specification of earnings functions: Tests and implications. Economics of Education Review, 10(2), 85-98.

Elliott, R. F. (1990). Labour economics: Comparative text. London: McGraw Hill.

Elsby, M. W., Shin, D., \& Solon, G. (2016). Wage adjustment in the Great Recession and other downturns: Evidence from the United States and Great Britain. Journal of Labor Economics, 34(S1), 249-291.

Goldin, C. (1989). Life-cycle labour-force participation of married women: Historical evidence and implications. Journal of Labour Economics, 7(1), 20-47. 
Gosling, A., Machin, S., \& Meghir, C. (1996). The changing distribution of male wages in the UK. Centre for Economic Performance Discussion Paper, 271.

Green, W. H. (1998). LIMDEP Version 7: User Manual, Econometric Software Inc.

Griliches, Z. (1977). Estimating the returns to schooling: some econometric problems. Econometrica, 45(1), 1-22.

Gronau, R. (1988). Sex-related wage differentials and women's interrupted labour careers-The chicken or the egg. Journal of Labour Economics, 6(3), 277-301.

Hausman, J. A. (1978). Specification tests in econometrics. Econometrica, 46(6), 1251-1271.

Heckman, J. J. (1979). Sample selection bias as a specification error. Econometrica, 47(1), 153-161.

Heckman, J. J., \& Sedlacek, G. (1985). Heterogeneity, aggregation and market wage functions: An empirical model of self-selection in the labour market. Journal of Political Economy, 93(6), 1077-1125.

Kennan, J. (1989). Simultaneous equation bias in disaggregated econometric models. Review of Economic Studies, 151-156.

Killingsworth, M. (1983). Labour supply. Cambridge University Press.

Kimmel, J., \& Kniesner, T. J. (1998). New evidence on labour supply: Employment versus hours elasticities by sex and marital status. Journal of Monetary Economics, 42, 289-301.

Lauer, C. (2000). Gender wage gap in West Germany: How far do gender differences in human capital matter? ZEW Working Paper, 00-07. Centre for European Economic Research (ZEW).

Lauer, C., \& Steiner, V. (2000). Returns to education in West Germany. ZEW Working Paper, 00-04. Centre for European Economic Research (ZEW).

Layard, R., Barton, M., \& Zabalza, A. (1980). Married women's participation and hours. Economica, 47, 51-72.

Lee, L. F. (1982). Some approaches to the correction of selectivity bias. The Review of Economic Studies, 49(3), 355-372.

Lydall, H. F. (1968). The structure of earnings. London: Oxford University Press.

Miles, D. (1997). A household level study of determinants of income and consumption. Economic Journal, 107, 1-25.

Mincer, J. (1974). Schooling, experience and earnings. New York: Columbia University Press.

Mroz, T. A. (1987). The sensitivity of an empirical model of married women's hours of work to economic and statistical assumptions. Econometrica, 55(4), 765-799.

Murphy, K. M., \& Welch, F. (1990). Empirical age-earnings profiles. Journal of Labor Economics, VIII(2), 202-229.

Nakamura, A., \& Nakamura, M. (1981). A comparison of the labour force behaviour of married women in the United States and Canada, with special attention to the impact of income taxes. Econometrica, 49(2), 451-489.

O’Leary, N. C., Murphy, P. D., Drinkwater, S. J., \& Blackaby, D. H. (1999). English language fluency and the ethnic wage gap in Britain. Discussion Paper, 99-09. Department of Economics, University of Wales Swansea.

Psacharopoulos, G. (1985). Returns to education: A further international update and implications. Journal of Human Resources, 583-604.

Rosen, S. (1972). Learning and experience in labour market. Journal of Human Resources, 7, 336-342.

Schultz, T. P. (1998). Inequality in the distribution of personal income in the world: How is it changing and why. Journal of Population Economics, 11, 305-405.

Spence, M., \& Stiglitz, J. (1975). The theory of screening, education, and the distribution of income. American Economic Review, 65, 283-300.

Staiger, D., \& Stock, J. H. (1997). Instrumental variables regression with weak instruments. Econometrica, 65(3), 557-586.

Taylor, M. F., Brice, J., Buck, N., \& Lane, E. P. (1999). British Household Panel Survey User Manual Volume A. Essex Data Archive.

Wisniewski, D. (Ed.). (1997). Monthly digest of statistics (No. 624). Office for National Statistics. 